\title{
Feeding potential of Cryptolaemus montrouzieri Mulsant on different species of mealybugs
}

\author{
ARCHANA T. AMBULE*1, V.S. DESAI ${ }^{1}$, D.L. PATIL ${ }^{2}$ AND N.R. TOKE ${ }^{2}$
}

${ }^{1}$ Department of Agriculture Entomology, College of Agriculture, Dr. Balasaheb Sawant Konkan Krishi Vidyapeeth, Dapoli, RATNAGIRI (M.S.) INDIA

${ }^{2}$ Department of Agriculture Entomology, Navsari Agricultural University, NAVSARI (GUJARAT) INDIA

\section{ARITCLE INFO \\ Received : 11.04 .2014 \\ Revised : 08.08 .2014 \\ Accepted : 23.08 .2014}

\section{KEY WORDS :}

Cryptolaemus montrouzieri,

Mealybug, Feeding potential

*Corresponding author:

Email: archana16sept@gmail.com

\begin{abstract}
An experiment was conducted to study the feeding potential of Cryptolaemus montrouzieri Mulsant on different species of mealybugs at Department of Agricultural Entomology, College of Agriculture, Dapoli. The feeding potential of $C$. montrouzieri on grubs and adults of mealy bugs jointly revealed that the total consumption of grub was much higher on M. hirsutus i.e. $144.4 \pm 15.64$ with their longevity of $12.10 \pm 2.1$ days than Phenacoccus solani and custard apple mealy bugs. Similar pattern of consumption was found in case of adults, where the female predator consumed more i.e. $443.90 \pm 27.13$ with longevity of $27.45 \pm 1.08$ days. The overall findings of the feeding potential showed that the Australian ladybird beetle nymphs and adults consumed more number of preys of $M$. hirsutus than other two species.
\end{abstract}

How to view point the article : Ambule, Archana T., Desai, V.S., Patil, D.L. and Toke, N.R. (2014). Feeding potential of Cryptolaemus montrouzieri Mulsant on different species of mealybugs. Internat. J. Plant Protec., 7(2): 373-376. 